\title{
RE-ACTUALIZATION OF PANCASILA VALUES ON LAW ESTABLISHMENT IN THE ECONOMIC GLOBALIZATION ERA
}

\author{
Ninuk Triyanti \\ Law Faculty of Governance IPDN \\ ninukzudan@yahoo.com
}

\begin{abstract}
Economic globalization which is characterized by the strengthening of capitalist liberalism greatly influences the legal order in Indonesia, so that many national legislation is found in the economic field that is loaded with capitalist liberals that do not reflect the values of the Pancasila. This research is intended to explain the importance of re-actualizing the Pancasila values and how to re-actualize the Pancasila values in the formation of laws in the economic field. The results showed that the re-actualization of the values of Pancasila in the formation of laws was an important requirement and as a means to achieve the goals of the country, namely to realize the welfare of the people. The method of actualizing Pancasila values in the formation of laws is carried out through 4 (four) stages in the process of forming laws, namely through the stages of planning the law, the stage of drafting the bill, the stage of discussion of the bill and the stage of ratification of the bill into law.
\end{abstract}

Keywords: Law establishment, Pancasila, Re-actualization.

\section{A. INTRODUCTION}

Globalization touches all fields of life, including economic, social, cultural, political, education, science and technology, and law, therefore globalization will greatly affect the lives of people and the administration of countries throughout the world.

One of globalization which brings fundamental changes to the economy of a country is economic globalization which is characterized by the existence of free trade or international trade and as a characteristic is trade and investment towards the liberalization of capitalism. Economic globalization requires the removal of all restrictions and barriers to the flow of capital goods and services ${ }^{1}$.

Economic globalization has a great influence on a country's legal system, because economic globalization causes the globalization of law $^{2}$, which has international legal implications affecting national law. Means the national state must make national rules that encourage the realization of an agreement in order to

1 Ngadino, PERANAN HUKUM DALAM GLOBALISASI EKONOMI, Jurnal Pembaharuan Hukum, Volume I No.1 Januari -April 2014, P.59-65.

2 Erman Rajagukguk, 1997, Peranan Hukum Dalam Pembangunan pada Era Globalisasi: Implikasinya Bagi Pendidikan Hukum Indonesia, Pidato Pengukuhan Guru Besar, Jakarta: FH-UI, p. 5-6. 
achieve common goals. For example in the field of international trade, the provisions of international trade in the framework of the WTO have encouraged each country to make national rules as a follow-up to the implementation of these provisions in a national setting. ${ }^{3}$

In Indonesia, the ratification of the WTO Agreement which was then followed by the enactment of Act No. 7 of 1994 is a gateway for the development of economic globalization. The ratification of the WTO Agreement has a juridical consequence that the Indonesian government must harmonize the provisions of its national law, especially in the economic field to conform to WTO Agreement standards. In other words, Indonesia must comply with all provisions that apply to all WTO member countries with all the consequences. Before the globalization of law, the government had full sovereignty to change and shape the laws of the economy and natural resources.4 But after Indonesia entered into the part of economic globalization, the consequences of many national legislative provisions led to liberalization and capitalism as a characteristic of globalization.

The fundamental question that needs to be considered in addressing

3 Sri Setianingsih Suwardi, 1998, Pembentukan Hukum Internasional di Organisasi Internasional dan Pengaruhnya terhadap Pranata Hukum Nasional Indonesia, dalam Beberapa Pemikiran Hukum Memasuki Abad XXI, Bandung: Penerbit Angkasa, p. 190.

4 Huala Adolf, 2011, Aspek-Aspek Negara Dalam Hukum Internasional, Jakarta: Rajawali Press, p. 51. economic globalization is related to the achievement of the objectives of the Unitary Republic of Indonesia as a welfare state is whether the liberalization system of capitalism as the foundation of economic globalization can support the achievement of the goals and ideals of the Unitary Republic of Indonesia?

In paragraph 4, the Preamble to the 1945 Constitution stated that the objective of the establishment of the Republic of Indonesia was to protect all Indonesians and all Indonesian blood and to advance public welfare, educate the nation's life, and participate in carrying out world order based on freedom, eternal peace and social justice. To realize the objectives of the country, the Republic of Indonesia sovereignty was formed which was based on the sovereignty of the people based on the Almighty God, humanity that was just and civilized, the unity of Indonesia and people led by wisdom in consultation / representation, and by realizing a social justice for all people Indonesia.

Pancasila contained in the Preamble to the 1945 Constitution is the basis of the state. If related to Article 1 of 1945 Constitution of the Republic of Indonesia as a constitutional state can realize the objectives of the Republic of Indonesia if carried out based on Pancasila.

The embodiment of one of the objectives of the state is to advance public welfare, or in other words, to realize the welfare of the people, carrying the implications of all development efforts in all areas of life carried out by the state, including 
economic and legal development, should be aimed at realizing people's welfare based on Pancasila.

Thus, the development of national law carried out through the formation of legislation must be in line with the values of the Pancasila to support the achievement of state objectives.

But the key is that, due to the demands of economic globalization, many laws have been found in the economic field that have capitalist liberalism and do not reflect the values of the Pancasila. For this reason, efforts are needed to re-actualize Pancasila values in the formation of laws. Re-actualization of the values of Pancasila is the process of applying or re-practicing the values of Pancasila in the life of the nation, state and society, including in the formation of laws ${ }^{5}$.

Based on the description above, the problems to be investigated are as follows:

1. Why should efforts be made to reactualize Pancasila values in the formation of laws in the era of economic globalization?

2. How to actualize the values of Pancasila into the formation of laws in the era of economic globalization?.

\section{B. DISCUSSION}

\section{The Importance of Re- actualization of Pancasila Values in the Formation of}

5 See Regulation of the Minister of Home Affairs Number 29 of 2011 concerning Regional Government Guidelines for the Revitalization and Actualization of Pancasila Values

\section{Laws in the Era of Economic Globalization}

The era of economic globalization strengthens the liberal system of capitalism, and it is clear that the liberal capitalist system cannot be applied in Indonesia because it contradicts the noble values of Pancasila. All order of life in Indonesia, including in implementing economic systems and legal systems must be in harmony with the values of the Pancasila because Pancasila is the basis of the state philosophy (philosophische grondslag), state ideology, national outlook on life (weltanschauung), the foundation of the nation, the mental life of the nation, the legal ideals (rechtsidee) of the Indonesian nation, the fundamental principles of the state (staatsfundamentalnorm) and the source of all sources of Indonesian law. Without being based on Pancasila, the country's goals as aspired to the founding of the nation will be difficult to achieve ${ }^{6}$

Rudolf Stamler stated that the ideals of the law provide benefits as a stellar star because he holds two sides "with the ideals of the law we can test positive laws in force, and to the ideals of law we can direct positive law as an effort with coercive sanctions

6 Sarbini Sumawita, Demokrasi Ekonomi; Beberapa Pemikiran Dasar, dalam Prospek Kajian MasalahMasalah nasional dan Internasional, Number 3 Volume 2, 1999, Center for Strategic and Policy Studies (PPSK), Yogyakarta, p. 212-213. 
towards something that is fair (zwangversuch zum richtigen ). Whereas Gustav Radbruch asserted that the ideals of the law not only functioned as a regulative benchmark, which tests whether a positive law is fair or not, but also also functions as a constitutive basis, which determines that without a legal ideal, the law will lose its meaning as law. ${ }^{7}$

Notonagoro stated that Pancasila is a legal ideal because of its position as the principal principle of the country's fundamental (staatsfundamentalnorm) which has the power as a ground norm. As a legal ideal, Pancasila guides all national legal products. All legal products are aimed at achieving the ideas contained in Pancasila . $^{8}$ While Jimly Ashiddiqie holds that Pancasia is a legal ideal as a yardstick in interpreting the constitution and as a guide in managing the life of the nation and state. $^{9}$ Pancasila as a legal ideal becomes a frame for the legal system in the Pancasila Law State, a unique system of Indonesia. ${ }^{10}$

7 Ashiddiqie Jimly, 2007, Ideologi, Pancasila, dan Konstitusi, Jakarta: Secretariat General and Registrar, MKRI.214.

8 Asshiddiqie Jimly, Gagasan Negara Hukum Indonesia, in the National Law Magazine, Number 1 of 2012, National Law Development Agency, Ministry of Law and Human Rights, Jakarta, National Law Magazine, Number 1 of 2012, National Law Development Board, Ministry of Law and Rights Human Rights.

9 Ibid, p. 215

10 Moh Mahfud MD, in his keynote address in the National Law State Conference and Dialogue, in
The position of the Pancasila as the source of all sources of law has the consequence that the power or rule of law comes from the Pancasila. Therefore, every law that is born must be based on Pancasila by containing the consistency of contents starting from the top to the lowest hierarchy. Pancasila is indeed a juridical connotation in the sense of giving birth to various laws and regulations which are arranged in a hierarchical manner and are sourced from it. This means that the applicable law must be a law that contains the values of the Almighty God, human values that are just and civilized, values that unite the Indonesian nation, democratic values and social justice values ${ }^{11}$.

For this reason, in facing the challenges of economic globalization, an economic system that is in accordance with the ideals of the Indonesian nation is needed, which Mubyarto calls the Pancasila economic system. ${ }^{12}$

The Pancasila economic system can be synthesized into a new perspective which does not fall into classical liberalism or neoliberalism or in the form of extreme socialism. In the Pancasila economic system,

the proceedings of the National Law State Conference and Dialogue with the theme: The State of Indonesian Law Where To Go, Jakarta, 9-10 October 2012.

11 Ibid, p. 12.

12 Mubyarto, 1987, Ekonomi Pancasila, Gagasan dan Kemungkinan, Jakarta: LP3ES, p. 53. 
individual rights still get recognition from the state. In the fifth precepts, the precepts of social justice for all Indonesian people do emphasize collectivity justice but the collectivity in the Pancasila economic system does not negate independence and recognition of individual rights. The fifth precepts of Pancasila are also revolutionary in order to overcome the crisis of global capitalism triggered by neoliberalism and the failure of socialism in managing economic life. The Pancasila economic system is the meeting point of liberalism and socialism with recognition of the power of Suora Materia (God) as an ethical and moral fundament. ${ }^{13}$

According to Mubyarto, there are 5 (five) characteristics of the Pancasila economic system which are imbued from the values of the Pancasila itself. These five features of the Pancasila economic system are interrelated to one another as a unified, integrated value. The five characteristics are, first, cooperatives are the pillars of the economy and are the most concrete form of joint effort. Second, the economy is driven by economic, social and moral stimuli. Unlike the capitalistic economic system, where the wheels of the economy are driven by economic stimulation, whereas in the Pancasia economic system,

13 R Saddam Al Jihad, 2018, Pancasila Ideologi Dunia, Sintetis Kapitalisme, Sosialisme, dan Islam, Jakarta: PT Pustaka Alvabet, p. 183-188. the wheels of the economy are not only driven by economic stimuli but are also driven by social and moral stimuli. Third, there is a strong will of the whole society towards a state of social equality, egalitarianism, according to humanitarian principles. In the Pancasila economic system, there is no "I want to be alone" spirit. The sense of social solidarity animates the doers in behavior. The sense of social solidarity must animate the Pancasila people. Fourth, the priority of economic policy is the creation of a resilient economy, which means that nationalism animates each economic policy. The Pancasila economic system gives the highest priority to the national economy. Fifth, in the Pancasila economic system it must be clear and clear that there is a balance between planning at the national level with the emphasis on decentralization in the implementation of economic activities to ensure economic and social justice The sense of social solidarity must animate the Pancasila people. Fourth, the priority of economic policy is the creation of a resilient economy, which means that nationalism animates each economic policy. The Pancasila economic system gives the highest priority to the national economy. Fifth, in the Pancasila economic system it must be clear and clear that there is a balance between planning at the national level with the emphasis 
on decentralization in the implementation of economic activities to ensure economic and social justice The sense of social solidarity must animate the Pancasila people. Fourth, the priority of economic policy is the creation of a resilient economy, which means that nationalism animates each economic policy. The Pancasila economic system gives the highest priority to the national economy. Fifth, in the Pancasila economic system it must be clear and clear that there is a balance between planning at the national level with the emphasis on decentralization in the implementation of economic activities to ensure economic and social justice ${ }^{14}$.

After the reform era, some opinions state that the realization of the economic system that animates the values of the Pancasila, is a populist economic system. According to Soeharsono Sagir ${ }^{15}$ In the populist economic system, sovereignty in the economy is in the hands of the people, and because of that people's economy is closely related to the idea of economic democracy which is nothing but the understanding of people's sovereignty in the economic field. The target of the populist

14 Dumairy and Tarli Nugroho2016, Ekonomi Pancasila Warisan Pemikiran Mubyarto, Yogyakarta: Gadjah Mada University Press, p. 56.

15 H Soeharsono Sagir, et al, 2009, Kapita Selekta Ekonomi Indonesia, Jakarta : Prenada Media Group, p. 1. economic system is the liberation of people's lives from poverty, ignorance, dependence, unfair treatment, environmental damage, and anxiety in looking at the future. Therefore, national development policies should not come out of the people's economic principles reflected in the principle of triple track development, namely pro-poor, pro-job, and pro-growth.

Furthermore, MPR Decree No. VI / MPR / 1999 concerning democratic economy, also stated that the mission of democratic economy is to "empower all national economic forces, especially small, medium and cooperative entrepreneurs by developing a fair market economy system, based on natural resources and productive human resources , independent, advanced, competitive, environmentally friendly, and sustainable. In other words, what is meant by a populist economic system is none other than a just market economic system.16

Whereas the

1945

Constitution Review Institute established by the MPR agreed that what was contained in Article 33 of the 1945 Constitution was the Pancasila economic system because the overall meaning of Article 33 was in accordance with the values of the Pancasila. ${ }^{17}$

The Pancasila economic system whose values are

16 Ibid, p. 60-68.

17 Ibid, p. 101 
contained in Article 33 of the 1945

Constitution can be applied consistently in national economic activities if the laws and regulations in the economic field also refer to the values of Pancasila and Article 33 of the 1945 Constitution.

However, in reality, because of the demands of globalization, many provisions of laws and regulations in the economic field are found, which only include the provisions of Article 33 of the 1945 Constitution in the preamble section without being followed up with consistent follow-up in the articles. In other words, the substance of various laws and regulations in the economic field is inconsistent with the provisions of Article 33 of the 1945 Constitution. In fact, it is not uncommon for the substance of the regulations contained in the formulation of various articles of laws and regulations in the economic field to be contrary to Article 331945 Constitution.

This shows that the legislation product in the economic field is nothing more than a heap of regulations laden with interests so that it loses its spirits and noble values. During this time, various laws and regulations in the economic sector favor the interests of certain groups. In fact, not infrequently a law in the economic field is merely made in order to meet the pressure and influence of foreign interests. Some examples of laws and regulations that were revoked by the Constitutional Court because they were considered contrary to Article 33 of the 1945 Constitution are Act No. 17 of 2012 concerning Cooperatives, Act No. 20 of 2002 concerning Electricity, Act No. 22 of 2001 concerning Oil and Gas, Act No. 7 of 2004 concerning Water Resources. The implication, Efforts to re-actualize Pancasila in the situation of globalization are based on the reason that Pancasila is a philosophy or deep thought about the procedures for the life of the nation and state formulated as an open ideology by the founders of the nation. The characteristics of Pancasila as an open ideology are expressly stated by the 6th President of Indonesia, Susilo Bambang Yudhoyono on the 21st anniversary of the birth of Pancasila, which states that "Pancasila is philosophy, the basis of the state and open ideology, open ideology, living ideology. ${ }^{18}$

As an open ideology, the values of Pancasila can follow the needs and development of the era without leaving his identity. Therefore, in the face of economic globalization, it is necessary to find harmonization between the material content of global values and Pancasila values so that the development process continues to adhere to the goals of people's

18 Yudi Latif, 2018, Wawasan Pancasila, Bintang Penuntun Untuk Pembudayaan, Jakarta: Mizan, p. 43 
welfare as mandated in paragraph 4 of the Preamble of the 1945 Constitution and Article 33 of the 1945 Constitution which constitutes an economic constitution.

\section{How to Re-actualize Pancasila Values in the Formation of Laws in the Era of Economic Globalization}

In order to be able to actualize the values of Pancasila into the law, the main element that must be addressed is the process of establishing laws that provide space to actualize the values of Pancasila into stages in the process of forming laws. In addition, every law formation must also pay attention to the principles and principles of the formation of legislation and principles of good content.

Basically, the formation of the law is a process and procedure that is carried out step by step in a planned, measured and well-coordinated manner involving many parties. To produce a good law, cooperation and legal awareness of the parties are needed. The process of establishing laws has been regulated in Act No. 12 of 2011 concerning Formation of Regulations and Regulations as amended by Act Number 15 of 2019 (hereinafter referred to as Law Establishing Regulations)

The Law on the Formation of Laws and Regulations explains that the process of forming a law covers 5 (five) stages, namely the stages of planning, drafting, discussion, ratification or enactment, and enactment. After promulgation, the law can be disseminated to the public. In the process of forming this law, the process and form of the embodiment of the values contained in the ideals of the Pancasila law into legal norms in the law can be carried out optimally.

The way to re-actualize Pancasila values can be carried out at 4 (four) stages of the process of forming laws, namely:

a. The planning stage

1) At the planning stage of the law, starting with the preparation of academic texts first .. The stage of preparing the academic manuscript is a crucial stage for actualizing Pancasila values because in the systematics of academic manuscripts there must be a description of the philosophical basis that underlies the importance of compiling the law the. For this reason, it must be ensured that the philosophical foundation as a basis for consideration of the drafting of the law must reflect the viewpoint of life, legal awareness, and the ideals of the law which encompasses the atmosphere of mysticism and the philosophy of the 
Indonesian nation which originates from Pancasila.

2) Medium-term and priority drafting stages and planning stages for drafting bills. To be able to actualize the values of Pancasila in this stage is to conduct an analysis of the needs of the law through research and surveys of the material to be regulated using the touchstone are the values of the Pancasila. If the content of the material already reflects the values of the Pancasila then the plan for drafting the law is included in the National Legislation Program or for the planning of drafting the bill outside the National Legislation Program, the plan for drafting the law can be carried out.

b. Stage of drafting the bill

At the stage of drafting this bill, the most crucial stage to actualize Pancasila values in the formation of legislation is the stage of the interministerial and / or interministerial committee meeting and the harmonization, rounding and monitoring of the conception facilitated by the Ministry of Law and Human Rights. At this stage, the content of the drafted bills must not contradict the values of the Pancasila, but must reflect the values of the Pancasila. c. Draft Discussion Phase

The discussion of the Bill between the Parliament and the Government is carried out in 2 (two) levels of discussion, namely: level I talks and level II talks in plenary meetings. Control over whether or not the values of Pancasila have been actualized can be exercised at each level of conversation. If at the level 1 discussion, the content of the bill does not conflict with the values of the Pancasila, the discussion will continue at the level II discussion. However, if it still contradicts the values of Pancasila, the discussion cannot proceed to the second level discussion but is repeated again to the discussion of the first level discussion at the next DPR session.

d. The stage of ratification of the bill by the President

The final control to reactualize Pancasila values can be carried out at the endorsement of the bill. If the President views that the content of the bill approved by the DPR and the President is still found to be in conflict with the values of the Pancasila, the President does not need to sign the bill into law. According to the Law Formation of Laws and Regulations, the law is still valid. When the law becomes effective, the parties concerned can submit a test stone to the law by submitting 
the right of judicial review to the Constitutional Court.

If all stages of the process of appealing the law have been completed, the Government disseminates the law to the entire community. Dissemination of the law can be done in various ways, for example by direct socialization to the public and in various social media, print media and electronic media. What needs to be socialized is not only related to the material contained in the law but also needs to be explained the relationship between the material contained in the law and the values of the Pancasila as the ideals of the Indonesian nation's law, the fundamental principles of the state (staatsfundamentalnorm) and the source of all sources of Indonesian law.

Finally, after the law takes effect in the community, the government, the DPR, and the DPD conduct a monitoring and review phase of the law, and will become material for future proposals. At this stage, the Government, the DPR and the DPD use the Pancasila values test stones in monitoring and reviewing the validity of the law. If the law is judged to be in effect incompatible with the values of the Pancasila then it can be taken into consideration to propose changes to the law in the National Legislation Program.

\section{CONCLUSION}

Re-actualization of Pancasila values in the formation of laws in the era of economic globalization is very important because the laws in the economic field are in line with Pancasila values that can be used as a means to achieve the country's goals, namely to realize the welfare of the people. Re-actualization of Pancasila values in the formation of laws can be carried out through 4 (four) stages in the process of forming laws, namely through the stage of planning the law, the stage of drafting the bill, the stage of deliberation of the bill and the stage of ratification of the bill into law. Furthermore, the actualization of Pancasila values can be strengthened through the dissemination of the law to the public by explaining the relevance of the material contained in the law with the values of the Pancasila and through monitoring and reviewing the applicable laws to ensure the validity of these laws in accordance with the values - the value of Pancasila. 


\section{BIBLIOGRAPHY}

\section{Book:}

Adolf Huala, 2011, Aspek-Aspek Negara Dalam Hukum Internasional, Rajawali Press, Jakarta;

Dumairy and Tarli Nugroho, 2016, Ekonomi Pancasila Warisan Pemikiran Mubyarto, Gadjah Mada University Press, Yogyakarta;

Erman Rajagukguk, 1997, Peranan Hukum Dalam Pembangunan pada Era Globalisasi: Implikasinya Bagi Pendidikan Hukum Indonesia, Pidato Pengukuhan Guru Besar, FH-UI, Jakarta, Sagir Soeharsono, et al, 2009, Kapita Selekta Ekonomi Indonesia, Prenada Media Group, Jakarta;

H Soeharsono Sagir, et al, 2009, Kapita Selekta Ekonomi Indonesia, Prenada Media Group, Jakarta;

Jimly Ashiddiqie, 2007, Ideologi, Pancasila, dan Konstitusi, Secretariat General and Registrar, MKRI, Jakarta;

Jimly Asshiddiqie, Gagasan Negara Hukum Indonesia, in the National Law Magazine, Number 1 of 2012, National Law Development Agency, Ministry of Law and Human Rights, Jakarta, National Law Magazine, Number 1 of 2012, National Law Development Board, Ministry of Law and Rights Human Rights;

Latif, Yudi, 2018, Wawasan Pancasila, Bintang Penuntun Untuk Pembudayaan, Mizan, Jakarta;

Moh Mahfud MD, in his keynote address in the National Law State Conference and Dialogue, in the proceedings of the National Law State Conference and Dialogue with the theme: The State of Indonesian Law Where To Go, Jakarta, 9-10 October 2012.

Moh Mahfud MD, Pancasila Sebagai tonggak Konveegensi Pluralitas Bangsa,, Key Lecture at National Workshop 2011, Implementation of Pancasila Values in Upholding Indonesian Institutionality, Monday, May 2, 2011 at Graha Sabha Prmana, UGM Yogyakarta.

Mubyarto, 1987, Ekonomi Pancasila, Gagasan dan Kemungkinan, LP3ES, Jakarta;

Ngadino, Peranan Hukum Dalam Globaisasi Ekonomi, dalam Jurnal Pembaharuan Hukum, Volume 1 Number 1 January-April 2014;

R Saddam Al Jihad, 2018, Pancasila Ideologi Dunia, Sintetis Kapitalisme, Sosialisme, dan Islam, Pustaka Alvabet, Jakarta;

Regulation of the Minister of Home Affairs Number 29 of 2011 concerning Regional Government Guidelines for the Revitalization and Actualization of Pancasila Values 
Sarbini Sumawita, Demokrasi Ekonomi; Beberapa Pemikiran Dasar, dalam Prospek Kajian Masalah-Masalah nasional dan Internasional, Number 3 Volume 2, 1999, Center for Strategic and Policy Studies (PPSK), Yogyakarta;

Sri Setianingsih Suwardi, 1998, Pembentukan Hukum Internasional di Organisasi Internasional dan Pengaruhnya terhadap Pranata Hukum Nasional Indonesia, dalam Beberapa Pemikiran Hukum Memasuki Abad XXI, Angkasa, Bandung; 